\title{
THE ROLE OF DIASTROPHISM IN THE REGIMEN OF GLACIERS IN THE ST. ELIAS DISTRICT, ALASKA
}

\author{
By Maynard M. Miller \\ (Lamont Geological Observatory, Columbia University)
}

\begin{abstract}
The "earthquake avalanche" theory was invoked by Tarr and Martin in 1914 to explain anomalous turn-of-the-century glacier advances in Yakutat Bay, Alaska. The concept was given credence by the fact that this bay was the epicenter of a series of severe earth tremors in the autumn of 1899 .

In considering alternative explanations, Tarr and Martin dismissed a record of excessive precipitation along this coast in the late 1870 's and 1880 's in the belief that the measurements were in error due to a "peculiarity in the method of measurement". The disputed data are now known to be consistent with observed and inferred regional climatological trends in the latter half of the 19th century. The case for the climatological control of glacier fluctuations in the St. Elias District is therefore reassessed. Reference is made to new and extensive evidence from other districts in southern Alaska where the earthquake influence was negligible. It is concluded that the fluctuation pattern in the Yakutat area was not unique and that the diastrophism to which these particular resurgences have been attributed was actually but a supplemental and generally minor factor in a widespread set of glacial advances initiated by climatological causes.

The theoretical implications of changes in load conditioned by climatological parameters over the broad névés of the St. Elias Mountains are briefly discussed with respect to orogenic activity in this tectonically sensitive region.
\end{abstract}

Zusammenfassung. Die ,Erdbeben Lawinen“ Theorie wurde im Jahre 1914 von Tarr und Martin zur Erklärung der um die Jahrhundertwende erfolgten abnormen Gletschervorstösse in der Yakutat Bay, Alaska herangezogen. Der Idee wurde dadurch Glauben geschenkt, dass diese Bucht im Herbst 1899 der Herd einer Serie von schweren Erdbeben war.

Bei der Erwägung anderer Erklärungen fertigten Tarr und Martin einen Bericht in den letzten I87oer und 8oer Jahren über übermässigen Niederschlag dieser Küste entlang ab, im Glauben, dass die Messungen auf Grund einer „Absonderlichkeit in der Messungsweise“ irrtümlich waren. Heute weiss man, dass die bestrittenen Daten mit beobachteten und hergeleitenden regionalen Witterungsverhältnissen in der letzten Hälfte des Igten Jahrhunderts in Einklang stehen. Der Fall der klimatologischen Kontrolle der Gletscherschwankungen im St. Elias Distrikt wird deshalb erneut erwogen. Es wird auf neue und ausgiebige Beweise von andern Distrikten in Südalaska Bezug genommen, wo der Einfluss von Erdbeben unbedeutend war. Die Schlussfolgerung ergibt, dass die Schwankungsschablone im Yakutat Gebiet nicht einzig in ihrer Art war, und dass die Verschiebung der diese speziellen Erhebungen zugeschrieben wurden, tatsächlich nichts weiter als einen ergänzenden und im ganzen unbedeutenden Faktor in einer sich weit erstreckenden Reihe von Gletschervorstössen, die klimatologischen Ursprungs waren, darstellte.

Die theoretischen Folgerungen von Druckänderungen, die durch klimatologische Parameter über dem weiten Firn der St. Elias Mountains bedingt sind, werden kurz in Bezug auf orogenische Aktivität in diesem tektonisch sensibeln Gebiet besprochen.

A Listing of possible causes of the simultaneous advance and retreat of glaciers has been given by Nichols and the writer. ${ }^{I}$ One hypothesis considered was the relationship between earth tremors and avalanching and dealt with the apparent effect on the regimen of certain coastal glaciers in southern Alaska. This concept is now reviewed in the light of recent findings.

The idea of "earthquake avalanching" was first invoked over 40 years ago by Professors Ralph Tarr and Lawrence Martin ${ }^{2}$ to explain the extraordinary advances in the early I90o's of glaciers in the vicinity of Yakutat Bay, Alaska. The basis for their theory was the series of violent earthquakes reported in Yakutat Bay in September r899. ${ }^{3}$ At one place along the shore of the inner bay (Disenchantment Fiord), the diastrophism was found to have produced an uplift of $47.5 \mathrm{ft}$. ( $14.5 \mathrm{~m}$.). The district is shown in the photograph in Fig. I (p. 292) and in the small plan in Fig. 2. The photograph shows the view towards the east along the axis of one of the westerly ranges of the St. Elias District in south-east Alaska. In the middle distance is Mt. Logan ( $19,850 \mathrm{ft}$., $6050 \mathrm{~m}$.) ; with Mt. Vancouver (I5,820 ft., $4820 \mathrm{~m}$.) and Mt. St. Elias (18,008 ft., $5489 \mathrm{~m}$.) on the sky-line to the right. The elevation of the glacier surface in the foreground is $2-3000 \mathrm{ft}$. $(610-9 \mathrm{I} 5 \mathrm{~m}$.) while far névés rest at $6-8000 \mathrm{ft}$. (I830-2440 m.) at a distance of approximately ioo miles (I6o km.). The photograph 
illustrates the great aereal extent and range of elevations included in the névé zone of the St. Elias Mountains as well as the intermontane nature of the main drainage basins. Yakutat Bay lies out of sight behind the sharp-tipped massif of Mt. St. Elias. The Gulf of Alaska is beyond the low peaks on the right horizon.

While considering the problem, Tarr and Martin were aware of excessive changes in the trend and magnitude of precipitation in this region over the preceding three decades, as indicated by meteorological records at Sitka, 200 miles $(300 \mathrm{~km}$.) down the coast; and they mentioned that such variations "complicate the solution of the problem of the cause of advancing glaciers and introduce difficulty in the definite elimination of the climatic

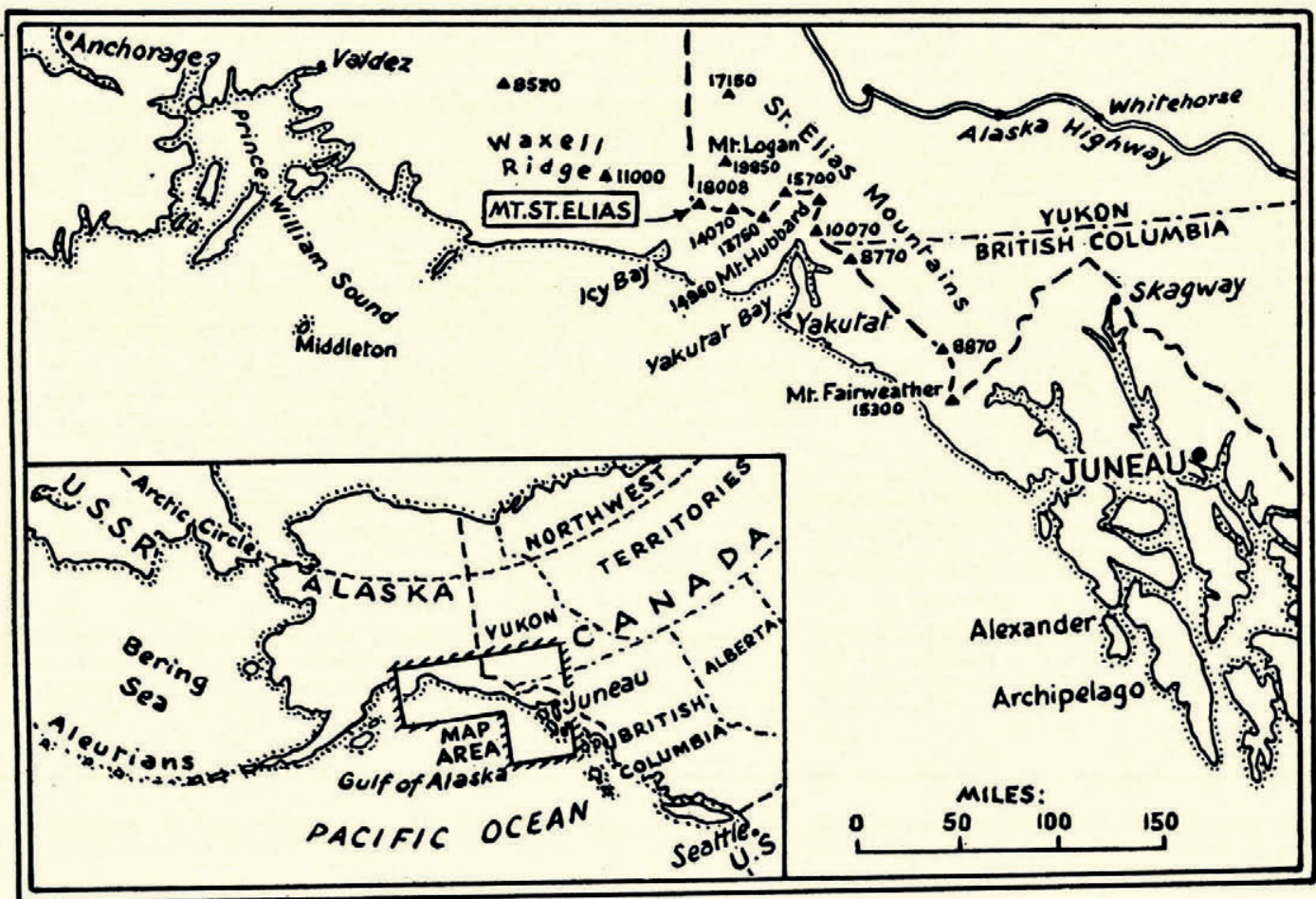

Fig. 2

hypothesis". 4 They were sufficiently convinced of the causal relationship of the earthquakes, however, that they dismissed further reference to the Sitka record in the belief that the reports of such extremes in rainfall and snowfall could only be due to errors in reading, most probably the result of some "temporary peculiarity in the method of measurement".

Eight years later a report published by the U.S. Weather Bureau 5 made specific mention of the "abnormal" records at Sitka in the I880's and stated that "while this record appears large, there is no reason to doubt its accuracy, or that the gauge was so exposed as to catch more than the actual precipitation". It would appear that this statement was in answer to Tarr and Martin's published inference of errors in measurement. The regular Weather Bureau station at Sitka is the only one in Alaska with continuous precipitation records back to the 1840 's. Between 1848 and 1876 , the average total precipitation (rain 
and w.e. snow) was 79 in. ( $2.01 \mathrm{~m}$.). The standard deviation in the annual records was small since the yearly mean did not exceed $94 \mathrm{in} .(2.39 \mathrm{~m}$.) in any one year of this 28 -year period and in only 2 years was the mean below 65 in. ( $1 \cdot 65 \mathrm{~m}$.). In 1876 , the annual mean was 79 in. $(2 \cdot 01 \mathrm{~m}$.$) , and there are no records between 1877$ and $188 \mathrm{I}$. The period of recorded excessive precipitation which Tarr and Martin questioned was from $188 \mathrm{I}$ to $\mathrm{r} 887$, being IO2 in. ( $2.59 \mathrm{~m}$.$) in 1882$; 102 in. in 1883 ; I I I in. $(2.82 \mathrm{~m}$.) in 1884 ; 103 in. $(2.62 \mathrm{~m})$. in 1885 ; and 140 in. $(3.56 \mathrm{~m}$.) in 1886 . The subsequent records up to 1915 averaged 80 in. $(2.03 \mathrm{~m}$.) per annum which is approximately that of the 28 -year period prior to 1876 .

The suggestion that great extremes in precipitation did occur in the late 1870 's and I880's at sea-level in south-eastern Alaska is supported by the apparent trends of temperature, as well as precipitation, discussed in a recent study. ${ }^{6}$ Unfortunately, at most of the U.S. Weather Bureau stations in southern Alaska continuous records were not maintained before I889. It is possible, however, to extrapolate the data for Alaska prior to that time. For example, Willett 7 has marshalled global statistics to show that the round-the-world mean winter sea-level temperature at lat. $60^{\circ} \mathrm{N}$. rose quite sharply by an increment of $2 \cdot 5^{\circ} \mathrm{F}$. $\left(\mathrm{r} \cdot 4^{\circ} \mathrm{C}\right.$.) in the single decade following 1876 . Over the past 75 years the world mean at lat. $60^{\circ} \mathrm{N}$. has approximated to the mean given by data from 64 stations in the panhandle of southern Alaska. Therefore, by referring to the $60^{\circ}$-latitude curves and using an average lapse rate of $3.5^{\circ} \mathrm{F}$. per $1000 \mathrm{ft}$. $\left(0.64^{\circ} \mathrm{C}\right.$. per $100 \mathrm{~m}$.), it may be presumed that the winter level of maximum solid precipitation shifted upward 700 to $800 \mathrm{ft}$. (210-240 m.) over the referenced ro-year period.

The mean winter temperature records at $60^{\circ} \mathrm{N}$. show a further increase of $0.5^{\circ} \mathrm{F}$. $\left(0.3^{\circ}\right.$ C.) up until 1902. Thus, between 1876 and the occurrence of the earthquakes in I899, one may infer about a quarter of a century of substantially increased snowfall at a level roughly $1000 \mathrm{ft}$. (300 m.) higher than in the preceding decade. That this change, in addition to the abnormal increase in total precipitation in the r88o's, must have had a pronounced effect on the magnitude and distribution of accumulation over the broad névés of the St. Elias Mountains is reasonable in view of the proximity of these nourishment zones to the coast. The regimen of multiple-elevation névés in the Coast Range north-east of Sitka and the probable lag to be expected in the response of glacier termini to major changes in levels of maximum snowfall in the highland have been considered elsewhere. ${ }^{8}$ Against the framework of this study of similar névés in an adjoining district, the foregoing facts lead to the conclusion that a meteorological cause, rather than diastrophism, was primarily responsible for the observed catastrophic growth of intermediate elevation glaciers in the Yakutat area in the first two decades after 1900.

The following empirical evidence based on the regional pattern of glacier fluctuations is cited to corroborate this interpretation.

(I) The Hubbard Glacier, the largest in Yakutat Bay and with a terminus 4 miles in width, is known to have been vigorously advancing in 1890,9 at least 9 years before the occurrence of the 1899 earthquakes. This observation is supplemented by reports between 1891 and 1897 of strong increases in crevassing on the highland ice tongues tributary to the huge Malaspina Glacier piedmont of the St. Elias District. ${ }^{\text {Io }}$

(2) The Hubbard Glacier has experienced a relatively steady advance, unlike the sporadic and irregular crowding forward which Tarr and Martin cite as specific evidence of the relationship of the earthquakes to the resurgence of other glaciers in the Yakutat area.

(3) Most of the main trunk glaciers which are nourished at high elevations in the other districts of south-eastern Alaska ${ }^{\text {II }}$ were characterized either by a pre-earthquake advance at the terminus or increased crevassing at higher levels prior to 1899 . Also, a fairly uniform velocity of movement has usually pertained on these termini. 
(4) A number of other glaciers in coastal Alaska have experienced pronounced postearthquake terminal advances, but lie in areas where no tremors were reported and where there has been no evidence of direct effects from the 1899 diastrophism.

(5) A number of the glaciers which advanced most vigorously in other districts at and just before the turn of the century arise in wide-strathed highland basins and on broad crestal plateaus where the bordering mountains are neither unusually high nor, in many cases, even glacierized (e.g. on the main ice fields of the Taku and Stikine River Districts). Additionally, the névés are broken by so few nunataks that the possibility of significant increases in nourishment from avalanching alone must be discounted, regardless of the intensity of the diastrophism.

(6) The most revealing fact with respect to the climatological relation is that of the ten glaciers (other than the Hubbard) which Tarr and Martin observed to be advancing after 1899 , and to which they ascribed important increases of load through earthquake avalanching, none has its prime source névé at elevations higher than $4500 \mathrm{ft}$. (1370 m.). Thus, their main nourishment areas were at relatively low or intermediate elevations compared to those of the large transection glaciers, such as the Hubbard. It is noted ${ }^{12}$ also that only one of these ten ice tongues reached its maximum extension after Tarr and Martin's last observation in 1913, and that all of them had begun to recede before 1920 .

It is also mentioned that since the 1899 diastrophism created world-wide interest in the Yakutat region, a disproportionate share of observation was focused on the behaviour of ice masses in this sector, compared to those in other districts along the North Pacific coast. Thus it is not surprising that the more extensive coverage of recent surveys, abetted by aerial photography, has revealed similar turn-of-the-century advances on glaciers throughout south-eastern Alaska, including those areas where the effects of the tremors were negligible. The regional comparisons therefore serve to emphasize that the Yakutat pattern cannot be considered as a purely local phenomenon due only to abnormal avalanche effects.

The writer does not wish to imply that diastrophism has had no effects on the glaciers in the Yakutat area. Undoubtedly, the 1899 earthquakes shook down large masses of snow and ice from the steep slopes of adjacent peaks, since here many of the glaciers are flanked by the highest and most massive mountains along the entire coast. Since the tremors occurred in September of an average warm summer, however, it may be assumed that considerable ablation and compaction of the annual snow-pack had already taken place, especially on the lower névés (i.e. below $4500 \mathrm{ft}$., $1370 \mathrm{~m}$.). Therefore, on those glaciers least exposed to avalanche bombardment from higher levels, the amount of material shaken down was probably minimal. In instances where avalanching from higher slopes adds substantially to a glacier's load, however, there would be a noteworthy increase in movement. This could magnify the terminal resurgences to an excessive degree and may explain the spectacular "thrusts" and spasmodic nature of some of the "advances" described by Tarr and Martin.

Although many narrow basins and highland canyons of the St. Elias Mountains are orographically conducive to an abundant avalanche supply, generally the region is characterized by broad valley glaciers and vast low-gradient, intermontane névés extending through a greater range of elevation than in any glacierized area in the world. This topography serves to accentuate the influence of horizontal and vertical shifts in the regional precipitation pattern. Thus, although the special effects of earthquake avalanching are recognized, recently extended observations on the overall pattern of Alaskan glacier behaviour strengthen the interpretation that the earthquakes were but a supplemental and generally minor factor in a widespread set of advances initiated about the turn of the century and conditioned fundamentally by meteorological causes.

As a purely theoretical corollary, it is suggested that during the r $9^{\text {th }}$ century excessively 
large changes occurred in the accumulation over the broad névés of the St. Elias Mountains and that the resulting alterations in load may, perhaps, have upset the orogenic balance sufficiently to have tripped off the earthquakes. Such changes would be but a contributory factor, of course, and would be effective only when the tectonic stress in the bedrock had already approached its limit of rupture.

The geological evidence is not at variance with the foregoing concept since the flanks of the westernmost ranges north and east of Yakutat are characterized by fault scarps and show other structures of recent tectonic origin. Furthermore, we are reminded that the epicenter of this most recent diastrophism was in inner Yakutat Bay. Since the bay lies in a zone of stress which is clearly sensitive to tectonic adjustment, a relationship to load changes accompanying major glacier fluctuations should be expected. It follows that we should also expect a relationship to any pronounced climatological changes affecting these fluctuations. It may be more than coincidental, therefore, that the largest névés and the most heavily glacierized mountains on the North American continent are in an active orogenic belt in the vicinity of Yakutat Bay.

$M S$. received 16 December 1957

\section{REFERENGES}

I. Nichols, R. L., and Miller, M. M. The Moreno Glacier, Lago Argentino, Patagonia; advancing glaciers and nearby simultaneously retreating glaciers. Fournal of Glaciology, Vol. 2, No. I I, 1952, p. 39-50.

2. Tarr, R. S., and Martin, L. Alaskan Glacier Studies. Washington, National Geographic Society, I914. Chap. 10.

3. Martin, L. The Alaskan earthquakes of 1899. Bulletin of the Geological Society of America, Vol. 21, r910, p. 339407.

4. Tarr, R. S., and Martin, L., op. cit., p. 176.

5. Summary of Climatological Data of Alaska, Section I. U.S. Dept. of Agriculture, U.S. Weather Bureau, I 922, p. 6.

6. Miller, M. M. The Glaciology of the Juneau Icefield, Southeastern Alaska (with special reference to the Taku Anomaly). Unpublished report to Office of Naval Research. 2 vols., I956, Chap. i 1 .

7. Willett, H. C. Temperature trends of the past century. Centenary Proceedings of the Royal Meteorological Society, 1950, p. 195-206.

8. Miller, M. M., op. cit., ref. 6, Chap. 12.

9. Russell, I. C. Glaciers of North America. Boston, 1897 (p. 74-1 30 deal with Alaskan glaciers).

10. Tarr, R. S., and Martin, L., op. cit., p. 52.

I I. Miller, M. M. The pattern and cause of recent glacier advances in Alaska. Transactions, American Geophysical Union, in the press. Abstract published: 37th Annual Meeting of the American Geophysical Union, Washington, D.C., April 1956.

12. Miller, M. M. Observations on the Regimen of the Glaciers of Icy Bay and Yakutat Bay, Alaska. Unpublished Master's Thesis, Columbia University, 1948. 71 p. 


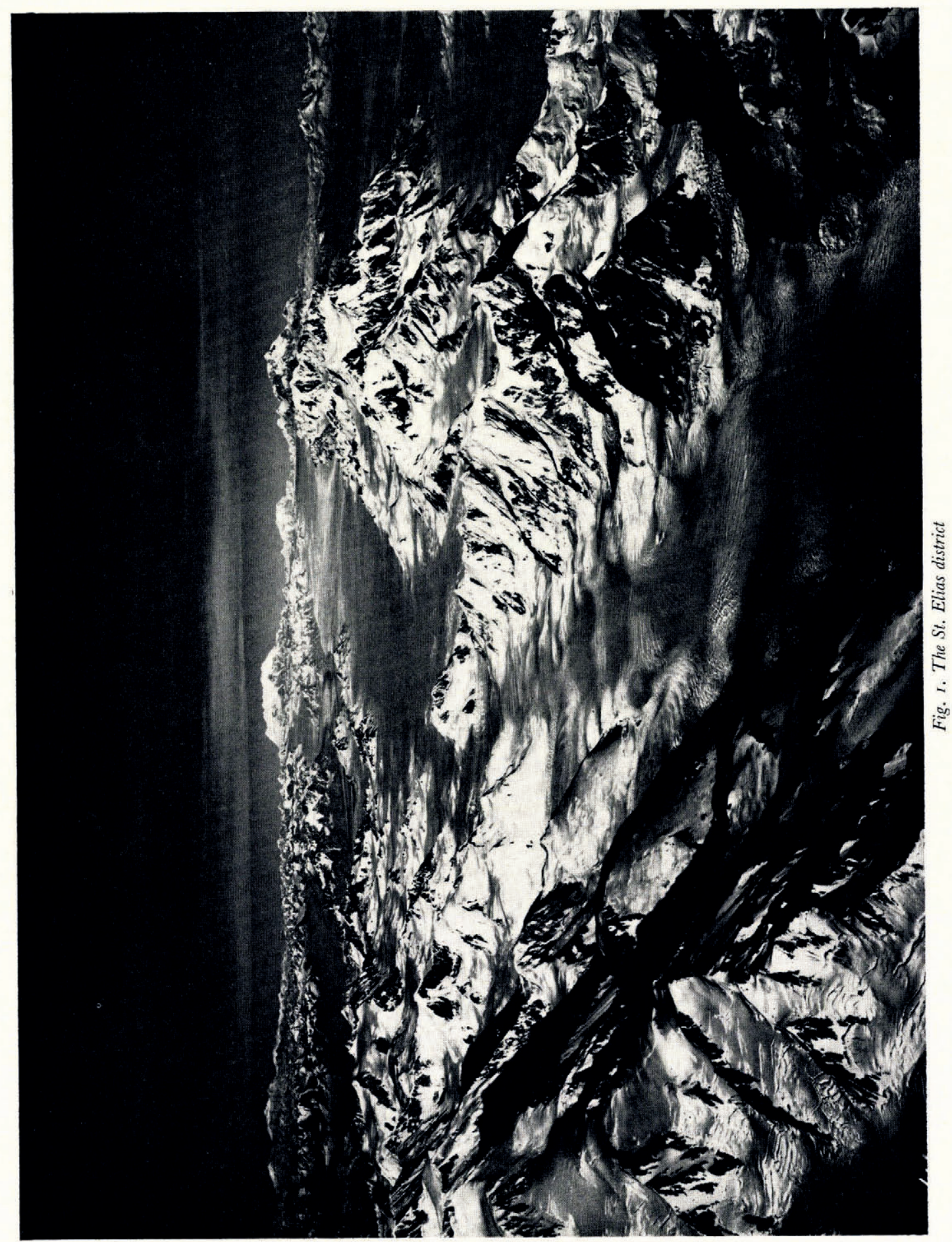

